comparing the patients with Down's syndrome and normal controls, a statistically significant decrease of the level of prealbumin and statistically significant increases of the levels of alpha $a_{2}$-macroglobulin and immunoglobulin $\mathrm{A}$ were noted. The level of $\operatorname{IgA}$ in patients with Down's syndrome is a matter of controversy, different authors finding increased, normal or even decreased levels ${ }^{7-10}$. Our results would be in line especially with those studies which revealed elevated $\operatorname{IgA}$ in older groups of patients as contrasted to normal values in young children ${ }^{10-12}$.

1 We are indebted to Prof. T.C. Bøg-Hansen, University of Copenhagen, for the helpful discussion of our results.

2 J. Kȩdziora and B. Wachowicz, Endokr. pol. 25, 14 (1974).

3 J. Kędziora, Endokr. pol. 24, 149 (1973).

4 B. Weeke, Scand. J. Immunol. 2, suppl. 1, 47 (1973).

5 B. Weeke, Scand. J. Immunol. 2, suppl. 1, 15 (1973).

6 C.M. Brogren and T. C. Bøg-Hansen, Scand. J. Immunol. 4, supp1. 2, 37 (1975).

7 A.W. Griffiths, P.E. Sylvester and E.M. Baylis, J. clin. Path. 22, $76(1969)$.

8 K. Reiser, C. Whitcomb, K. Robinson and M.R. MacKenzie, Am. J. menth. Defic. 80, 613 (1976).
Staining of the gels with naphthyl acetates yielded a typical pattern of esterase activity contributed by cholinesterase (brownish-red) and arylesterase (orange) ${ }^{6}$. It is shown by this study that the electrophoretic mobilities of both plasma esterase activities are unaltered in Down's syndrome.

The behaviour of the protein fractions studied in the case of translocation $\mathrm{G} 21 / 22$ is noteworthy as it differs in many respect from that typical for trisomy G-21 (figure 2). However, the scarcity of material precludes a broader discussion of this point at present.

\title{
Significant differential gene duplication without ancestral tetraploidy in a genus of mexican fish ${ }^{1}$
}

\author{
B. J. Turner ${ }^{3}$, R. R. Miller and E. M. Rasch ${ }^{4}$
} Museum of Zoology, University of Michigan, Ann Arbor (MI 48109, USA), and Department of Biology, Marquette
University, Milwaukee (WI 53233, USA), 24 September 1979

Summary. A comparison of the protein products of 20-25 structural gene loci among the known species of the goodeid fish genus Skiffia suggests that at least 4 loci (16-20\%) have undergone species-specific duplications (or, in 1 case, apparent loss) during the evolution of the genus. The species are clearly diploids, and the data therefore indicate that even a large proportion of differentially duplicated loci within a group of related fish species is not critical evidence of common tetraploid ancestry. Differential duplication of structural gene loci may be an important component of the genetic differences that separate congeneric conventional diploid species.

In teleost fishes, gene duplications and species-specific differences in the nature and number of homologous loci have been detected mainly among the genomes of the Palearctic cyprinids $^{5-8}$ (barbs and minnows, most notably including the carp) ${ }^{9}$, catostomids (suckers) ${ }^{10}$, cobitids (loaches) ${ }^{11}$ and salmonids (salmons, trouts, and whitefishes) ${ }^{12,33}$. The differentially duplicated homologous loci in all of these families have been attributed to ancestral tetraploidy (usually allotetraploidy) followed by loss of some of the duplicated loci by "rediploidization" $10,34-40$ (fixation of mutations to functional silence, but possibly also including loss of genes by deletion). The little-known fish genus Skiffia presents what appears to be a case of significant differential structural gene duplication among congeneric fish species that clearly does not involve ancestral tetraploidy.

The 4 species of the genus (figure 1) are part of an impressive adaptive radiation on the Mexican plateau of cyprinodontoid fishes of the endemic family Goodeidae into habitats and trophic niches usually occupied by several diverse fish families ${ }^{41}$. Cytophotometric data (table) indicate that all 4 species are at the same ploidy level. They are not tetraploids with respect to other goodeids (average DNA content $=2.17 \pm 0.03 \mathrm{pg} /$ diploid nucleus, Turner and Rasch, unpublished data) or other cyprinodontoid fishes. For example, the rivuline and funduline killifishes, morphologically generalized and likely to be ancestral to all other new world cyprinodonts ${ }^{42}$, have diploid nuclear DNA contents that range from $1.4-3.2 \mathrm{pg}$, average $=2.5 \pm 0.3 \mathrm{pg}^{43}$. The evidence of species-specific structural gene duplications in
Skiffia is taken from electrophoretic comparisons of the protein products of approximately $20-25$ structural gene loci.

1. Hemoglobins. These proteins showed species-specific patterns (figure 2, a) by gel electrophoresis or isoelectric focusing; these patterns differ markedly in the number of components displayed, as well as in their electrophoretic mobility. The number of discernible hemoglobins in each species, and the minimum number of globin chains (=number of globin genes) necessary to form the phenotype of each species, given 2 different models of hemoglobin structure, are presented in the table. The hemoglobins of S. multipunctata and $S$. francesae were further analyzed by gel isoelectric focusing of disassociated globin preparations ${ }^{30}$ in $8 \mathrm{M}$ urea (figure $2, \mathrm{~b}$ ). The results are consistent with differences in the number of globin chains in the 2 species, postulated in the table.

2. Malate dehydrogenase (MDH, figure 3,a). There are apparently 3 loci that encode malate dehydrogenases in nearly all goodeids (Turner, unpublished data) and all other cyprinodontoid fishes so far studied ${ }^{44} .2$ of these, MDH-1 and MDH-3, encode cytosolic enzymes; a 3rd, $\mathrm{MDH}-2$ encodes the mitochondrial enzyme. The MDH-1 phenotypes of S. bilineata and S. lermae were invariant and identical. The most frequent MDH-1 phenotype in S. multipunctata was identical to that of the 1st 2 species: 2 specimens of S. multipunctata were heterozygous at the MDH-1 locus (genotype MDH-1a/MDH-1b). All specimens of S. francesae appeared to be heterozygous at the MDH-1 
Comparisons of nuclear DNA content, hemoglobin phenotype, and apparent number of homologous gene loci in 4 species of the genus Skiffia (family Goodeidae)

\begin{tabular}{|c|c|c|c|c|}
\hline & S.bilineata & S.lermae & S.multipunctata & S.francesae \\
\hline 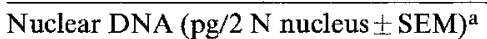 & $2.07 \pm 0.03$ & $2.27 \pm 0.07$ & $1.93 \pm 0.03$ & $1.90 \pm 0.06$ \\
\hline Number of $\mathrm{Hb}$ bands & $5-2$ & 6 & 8 & 6 \\
\hline Minimum number globin chains & & & & \\
\hline (=number globin genes); model $1^{\mathrm{b}}$ & 6 & 7 & 9 & 7 \\
\hline Minimum number globin chains & & & & \\
\hline$\left(=\right.$ number globin genes) model $2^{\mathrm{c}}$ & 4 & 4 & 5 & 4 \\
\hline Number of MDH-1 loci & 1 & I & 1 & 2 \\
\hline Number of $a$ GPD loci & 1 & 1 & 1 & $\overline{2}$ \\
\hline Number of 6 PGD loci & 1 & $\hat{1}$ & 2 & 2 \\
\hline Number of parvalbumin loci & 3 & 2 & 2 or $3^{d}$ & 3 \\
\hline
\end{tabular}

a Determined by DNA-Feulgen cytophotometry of erythrocytes as described earlier 4,5 , by these methods, chicken erythrocytes contain $2.5 \mathrm{pg}$ DNA per diploid nucleus; $\mathrm{b}$ Model 1: Hb structure is $a_{2} \mathrm{X}_{2}$, i.e. asymmetrical tetramers are not permitted. Globin differences between $S$. multipunctata and S.francesae (figure 2,b) are consistent with this model; c Model 2 : Hb structure is $a_{2} \mathrm{x}_{1} \mathrm{y}_{1}$, i.e. asymmetric tetramers are permitted. The globin analysis (figure 2,b) was not consistent with the predictions of this model, but asymmetric tetramers have been well documented in other fish groups 29,30 ; S.multipunctata sample was polymorphic for the number of parvalbumins detected.

locus (presumptive genotype MDH-1a/MDH-1c); the relative staining intensities of the $3 \mathrm{MDH}-1$ allozymes in the phenotype were identical to those of the obvious heterozygotes in S. multipunctata. The 'heterozygous' MDH-1 phenotype of $S$. francesae was invariant in all 12 field-caught specimens and in 64 laboratory-reared $F_{1}$ progeny. It is therefore reasonable to suggest that the MDH-1 phenotype of $S$. francesae is that of a fixed heterozygote resulting from duplication of the MDH-1 locus. If this is correct, it is probably that the gene duplication is confined to $S$. francesae alone. The MDH-1 variants in S. multipunctata had phenotypes with the symmetrical relative allozyme staining intensities of typical heterozygotes at a locus encoding a dimeric protein. If a 2nd MDH-1 locus were present and active the relative staining intensities of the allozymes would have been markedly skewed toward the product of the ' $a$ ' allele.

3. alphaglycerolphosphate dehydrogenase. Data in the table.
4. 6-phosphogluconate dyhydrogenase (6PGD, figure 3,b). This enzyme is easily detected in hemolysates and homogenates of nearly all tissues; it was separately surveyed in eye and liver homogenates in our samples. The 6PGD phenotypes of S. bilineata and S. lermae were divergent but monomorphic within species; the single-banded phenotype was identical in all tissues. Eye homogenates of S. multipunctata and $S$. francesae displayed 2 bands of roughly equal staining intensity. The slower of these 2 bands was of slightly increased relative staining intensity in liver homogenates; the latter also contained small amounts of a $3 \mathrm{rd}$, slower band. This enzyme is a dimer, is encoded by a single locus, and displays symmetrical 3-banded patterns in heterozygotes in a great variety of organisms, including many cyprinodontoid fishes (Turner, unpublished data); to our knowledge, post-translational modifications of the enzyme that could result in nongenetic electrophoretic heterogeneity are rare or absent. It is therefore reasonable to postulate that the 6PGD phenotype of S. multipunctata and S. francesae is the

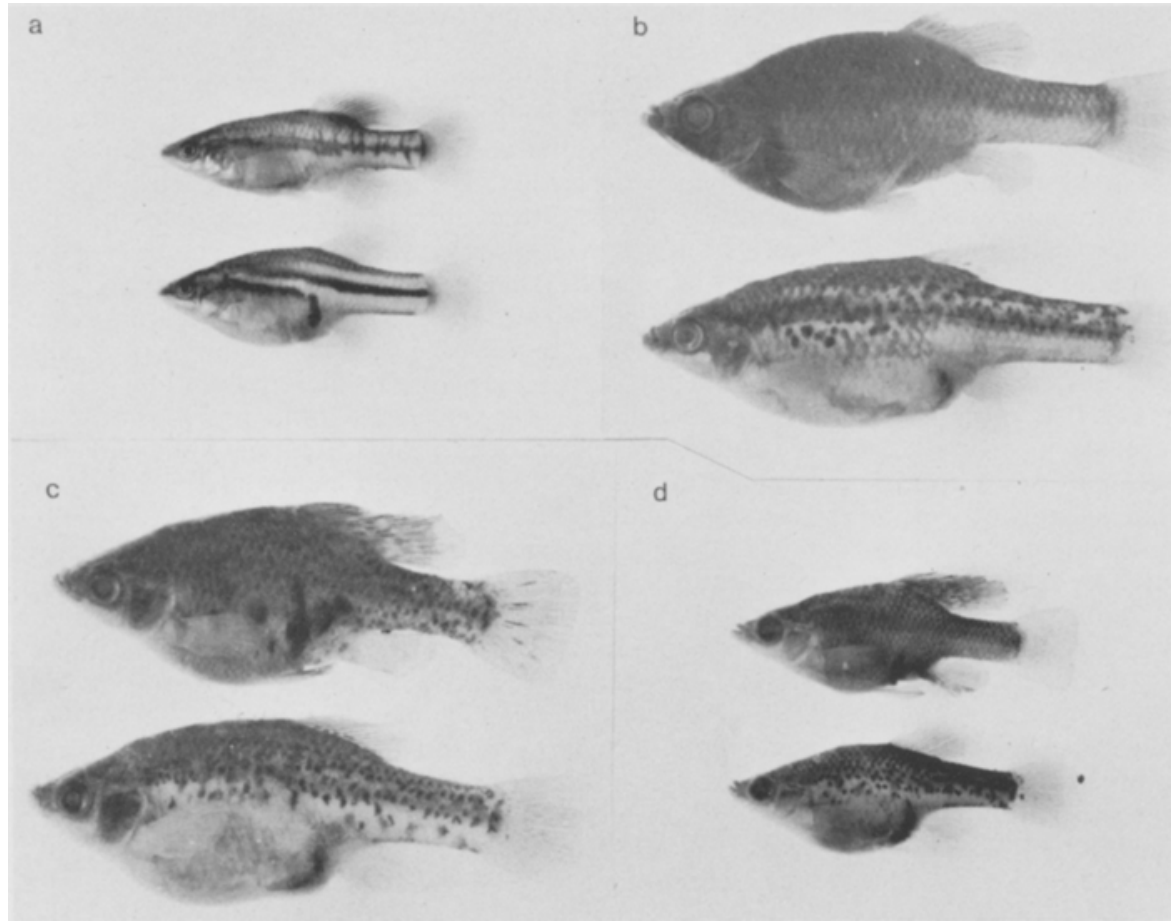

Fig. 1. The known species of the goodeid fish genus Skiffia; males above females. a Skiffia bilineato (UMMZ 198860, male is $25 \mathrm{~mm}$ standard length (SL)); $b$ S. lermae (UMMZ 198812, male is $45 \mathrm{~mm}$ SL); c S.multipunctata (UMMZ 202426 , male is $42 \mathrm{~mm} \mathrm{SL}) ; d S$. francesae (UMMZ 185588, male is $28 \mathrm{~mm} \mathrm{SL}$ ). Note the morphological similarity of the last 3 species. Details of the samples used in this study, and the distribution and ecology of the genus, are available from the first author. 

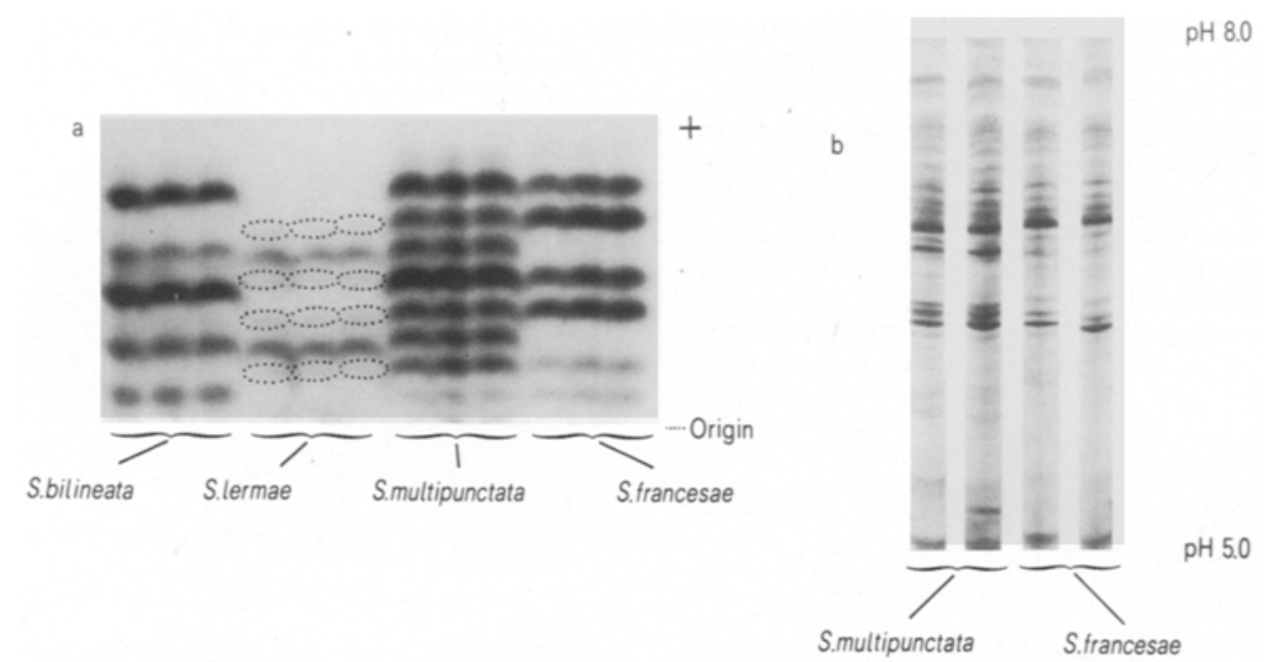

Fig.2. a Comparison of native (cyanomet-) hemoglobins in the 4 Skiffia species by starch gel electrophoresis of hemolysates prepared from gill tissue (Tris-EDTA-borate buffer, $\mathrm{pH} 8.6$, containing $0.05 \% \mathrm{KCN}$; benzidine stain). Dotted regions in the S.lermae patterns are very light-staining bands that could be discerned by eye but could not be reproduced photographically; $b$ Analysis of globin chains in S.multipunctata and S. francesae by narrow-gradient gel isoelectric focusing in $8 \mathrm{M}$ urea (5\% total monomer, $1 \%$ Servalyte $5-7,1 \%$ Servalyte $6-8,0.1 \%$ Servalyte $3-10$, stained with $0.4 \%$ Coomassie blue G250 in 5\% perchloric acid). Globins were prepared by cold acid acetone precipitation ${ }^{30}$ of gill hemolysates, followed by solution of the precipitated protein in $10 \mathrm{M}$ urea and dialysis against $8 \mathrm{M}$ urea for $2-3 \mathrm{~h}$ at $37^{\circ} \mathrm{C}$. Note that the patterns are consistent with the presence of at least 2 globins (arrows) in S. multipunctata that are absent in S.francesae. Lighterstaining bands on these gels are probably serum proteins, which contaminate gill hemolysates at low levels.

Subunit

composition

$\mathrm{MDH}-3$ (CC)

$\mathrm{MDH}-2$

$(B B+A C$;

heterodimer)

$\mathrm{MDH}-1(\mathrm{AA})$

Origin

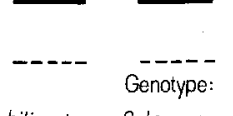

S. bilineata S. lermae

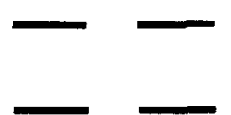

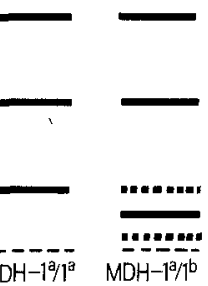

S. multipunctata $\oplus$

b

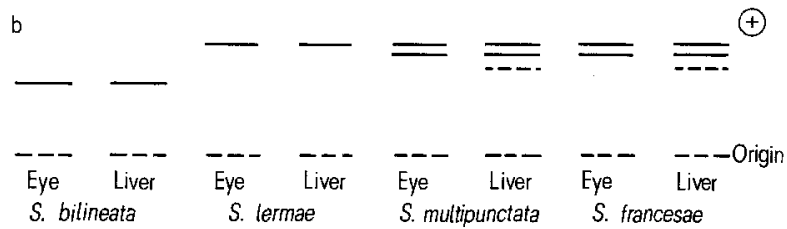

result of the interaction of the products of 2 homologous loci, 5PGD-1 and 6PGD-2. The 6PGD-1 locus is more active, and the zymograms of most tissues contain 6PGD-1 homodimers and 6PGD-1/6PGD-2 heterodimers only; the 6PGD-2 locus is relatively more active in the liver, and a small number of 6PGD-2 homodimers can be detected in liver homogenates. This hypothesis suggests that a duplication of the 6PGD structural gene occurred in the common ancestor of S. multipunctata and S. francesae, and the duplicated loci subsequently diverged in their tissue expression. We have been unable to detect any intraspecific polymorphism in either S. multipunctata or S. francesae that might provide a critical test of this 2-locus hypothesis (e.g., by demonstrating independent variation), and have thus been unable to directly eliminate the unlikely alternative hypothesis of postranslational modification in the 2 species of the product of a single 6PGD locus.

5. Parvalbumins (figure $3, \mathrm{c}$ ). 3 parvalbumins were detected in muscle homogenates from all specimens of S. bilineata and S. francesae, though only 1, parvalbumin-3 (pl approximately 4.1) was identical in both species. 2 parvalbumins were detected in all specimens of $S$. lermae. 18 specimens of S. multipunctata had a 2-parvalbumin phenotype identical to that of S.lermae, 30 had a 3-parvalbumin phenotype

punctata in both number and relative staining intensities of bands; $b$ 6-phosphogluconate dehydrogenase (6PGD) phenotypes in the 4 Skiffia species (starch gel electrophoresis, $12 \%$ electrostarch, TrisEDTA-borate buffer, $\mathrm{pH} 8.6$; patterns independent of the addition of exogenous NADP to the gel or electrolyte solutions). Both bands detected in eye homogenates of $S$. multipunctata and $S$. francesae are present in homogenates of all other tissues; the lightstaining, slow band was detected in liver homogenates only; $c$ parvalbumins from muscle homogenates of the 4 species as compared by electrophoresis in $12 \%$ polyacrylamide gels (above) and by narrow gradient ( $2 \%$ Servalyte $3-5$ ) isoelectric focusing (below). Though polyacrylamide gel electrophoresis is a standard technique for the analysis of parvalbumins ${ }^{46}$, isoelectric focusing resolved additional components. Note that S.multipunctata is polymorphic for the number of parvalbumins observed, and that there are only 2 parvalbumins in $S$. lermae. 
identical to that of $S$. francesae. Since 3 parvalbumin loci are present in the genomes of nearly all goodeid fishes (Turner, unpublished data) we assume that the common ancestor of all 4 Skiffia species had 3 parvalbumin loci, and that the 2-parvalbumin phenotype of $S$. lermae resulted from the loss (=mutation to silence?) of 1 of the ancestral parvalbumin genes. Our sample of S.multipunctata is apparently polymorphic for the number of parvalbumin genes present or expressed.

The number of loci that apparently encode the homologous groups of proteins in each species are summarized in the table.

1 Supported by NSF grants DEB76-20958 (BJT), DEB77-03257 (EMR) and DEB77-17315 (RRM).

2 Acknowledgments. We thank B.L. Brett for helpful discussions, D.L. Grosse for technical assistance, and A. Esen for editorial advice.

3 Present address: Department of Biology, Virginia Polytechnic Institute and State University, Blacksburg (VA 24061, USA).

4 Present address: Department of Biophysics, College of Medicine, East Tennessee State University, Johnson City (TN 37601, USA).

5 S. Ohno, J. Muramoto, L. Christian and N. B. Atkin, Chromosoma $23,1(1967)$.

6 K. Bender and S. Ohno, Biochem. Genet. 2, 101 (1968).

7 J. Klose, U. Wolf, H. Hitzeroth, H. Ritter and S. Ohno, Humangenetik 7, 245 (1969).

8 J. Schmidtke and W. Engle, Experientia 28, 976 (1972).

9 S.D. Ferris and G.S. Whitt, Experientia 33, $1299(1977)$

10 S.D. Ferris and G.S. Whitt, Nature 265, 258 (1977).

11 S.D. Ferris and G.S. Whitt, Biochem. Genet. 15, 1097 (1977).

12 F.W. Allendorf and F.M. Utter, Genetics 74, 647 (1973).

13 F.W. Allendorf, F.M. Utter and B.P. May, in: Isozymes IV: Genetics and Evolution, p.415. Ed. C.L. Markert. Academic Press, New York 1975.

14 F.W. Allendorf and F.M. Utter, Hereditas 82, 19 (1976)

15 Y.P. Altukhov, E.A. Salmenkova and G.D. Sachko, Dokl. (Proc.) Acad. Sci. USSR Biol. 195(3), 711 (1971)

16 G. Bailey, G.T. Cocks and A.C. Wilson, Biochem. biophys. Res. Commun. 34, 605 (1969).

17 G. Bailey, A.C. Wilson, J.E. Halver and C. L. Johnson, J. biol. Chem. 245, 5927 (1970).

18 G. Bailey and L. Theye, in: Isozymes IV: Genetics and Evolution, p. 401. Ed. C.L. Markert. Academic Press, New York 1975.
19 J.W. Clayton, D. Tretiak, B. Billeck and B. Thssen, in: Isozymes IV: Genetics and Evolution, p. 433. Ed. C.L. Markert Academic Press, New York 1975.

20 W. Engel, J. Op't-Hoff and U. Wolf, Humangenetik 9, 157 (1970).

21 J. Klose, U. Wolf, H. Hitzeroth, H. Riter, N.B. Atkin and S. Ohno, Humangenetik 5, 190 (1968)

22 S.R. Landrey, R. Applegate and J.M. Cardenas, Comp. Biochem. Physiol. 60B, 383 (1978).

23 E.J. Massaro and C.L. Markert, J. exp. Zool. 168, 223 (1968).

24 E.J. Massaro and C.L. Markert, J. exp. Zool. 179, 247 (1973).

25 G. L. Reinitz, Biochem. Genet. 15, 445 (1977).

26 A.P. Ronald and H. Tsuyuki, Comp. Biochem. Physiol. 39, 195 (1971).

27 H.H. Ropers, W. Engel and U. Wolf, in: Genetics and Mutagenesis of Fish, p.319. Ed. H.H. Schroder. Springer, New York 1973.

28 J. Schmidtke, N. Atkin and W. Engel, Biochem. Genet. 13, 301 (1975).

29 H. Tsuyuki and A.P. Ronald, J. Fish. Res. Bd Can. 27, 1325 (1970).

30 N.P. Wilkins, J. Fish. Res. Bd Can. 25, 2651 (1968).

31 N.P. Wilkins, Biochem. biophys. Acta 214, 52 (1971).

32 S. N. Williscroft and H. Tsuyuki, J. Fish. Res. Bd Can. 27 $1563(1970)$

33 U. Wolf, W. Engel and J. Faust, Humangenetik 9, 150 (1970).

34 F.W. Allendorf, Nature 272, 76 (1978).

35 W. Engel, J. Schmidtke and U. Wolf, in: Isozymes IV: Genetics and Evolution, p.449. Ed. C.L. Markert. Academic Press, New York 1975

36 S.D. Ferris and G.S. Whitt, Syst. Zool. 27, 189 (1978)

37 S. Ohno, U. Wolf and N. B. Atkin, Hereditas 59, 169 (1968).

38 S. Ohno, J. Muramoto, J. Klein and N.B. Atkin, in: Chromosomes Today II, p. 139. Ed. C.D. Darlington and K. R. Lewis. Oliver and Boyd, London 1969.

39 S. Ohno, Evolution by Gene Duplication. Ed. Springer, New York 1970.

40 S. Ohno, in: Animal Cytogenetics 4: Chordata 1: Protochordata, Cyclostomata and Pisces. p.92. Ed. B. John. Borntraeger, Berlin 1974.

41 R.R. Miller and J.M. Fitzsimons, Copeia 1 (1971).

42 D.E. Rosen and R.M. Bailey, Bull. Am. Mus. nat. Hist. 126 3 (1963).

43 R. Hinegardner, Am. Nat. 102, 517 (1968).

44 G.S. Whitt, Experientia 26, 734 (1970).

45 E.M. Rasch, R.M. Darnell, K.D. Kallman and P. Abramoff, J. exp. Zool. 160, 155 (1965).

46 J.F. Pechere, T. Demaille and J.P. Capony, Biochem. biophys. Acta. 236, 391 (1971)

\title{
Effect of different food plants on the development and reproduction of Heliothis armigera (Hbn.)
}

\author{
N. Dhandapani and M. Balasubramanian
}

Department of Agricultural Entomology, Tamil Nadu Agricultural University, Coimbatore-641 003, Tamil Nadu (India), 6 November 1979

Summary. Studies on the rate of development and reproduction of Heliothis armigera Hbn. on 8 different food plants at $26 \pm 2{ }^{\circ} \mathrm{C}$ revealed that cotton was the most suitable host and tomato and sorghum were the least suitable.

The gram pod borer, Heliothis armigera, is a polyphagous and notorious pest causing economic damage to several crop plants. Outbreaks of this pest in cotton crops are closely associated with the availability of other host plants in the environment ${ }^{1}$. So it is necessary to study the suitability of alternative host plants for its development, using some economically important plants. The net reproductive rate, weight of the pupae and percentage of pupae and moths formed were the criteria used to compare different host plants.
Materials and methods. The food plants used for this study were bengalgram, (Cicer arietinum $\mathbf{L}$.), redgram (Cajanus cajan L.), lab-lab (Dolichos lab-lab L.), (Gossypium hirsutum L.), tomato (Lycopersicon esculentum Mill.), sorghum (Sorghum vulgare Pers.), maize (Zea mays L.) and sunflower (Helianthus annuus L.). A laboratory culture of H. armigera was used for this study. A known number of adult pairs were released for egg-laying in cages $(30 \times 30 \mathrm{~cm})$. Eggs laid on white muslin cloth were collected with a wet camel-hair brush and 100 eggs were kept for hatching. 